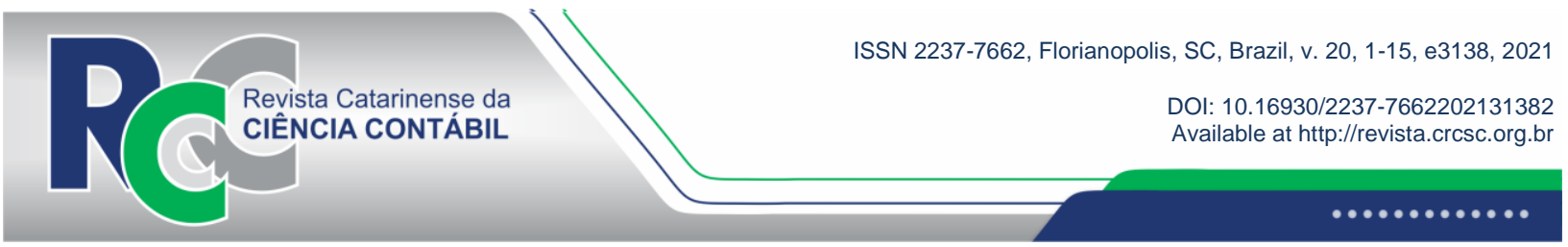

\title{
ACCOUNTING FIRMS AND THEIR RELATIONSHIP WITH CLIENTS IN THE FACE OF THE COVID-19 CRISIS
}

\author{
FABIANA FRIGO SOUZA \\ Federal University of Parana. Address: Av. Pref. Lothario \\ Meissner, 632| Jardim. Botanico | 80210-070 | Curitiba/PR| \\ Brazil. \\ (D) https://orcid.org/0000-0003-0475-8997 \\ fabiiana_fs@hotmail.com
}

\section{RICARDO BIERNASKI KACHENSKI}

Federal University of Parana. Address: Av. Pref. Lothario Meissner, 632| Jardim. Botanico | 80210-070 | Curitiba/PR| Brazil.

(1) https://orcid.org/0000-0001-9577-2836

ricardobiernaski@yahoo.com

\section{FLAVIANO COSTA}

Federal University of Parana. Address: Av. Pref. Lothario Meissner, 632| Jardim Botanico | 80210-070 | Curitiba/PR | Brazil.

(1) https://orcid.org/0000-0002-4694-618X

flaviano@ufpr.br

\begin{abstract}
Management support can be understood as the area that assists in decision-making related to management (organizational performance, financial planning, and control). It is suggested that the changes brought about by COVID-19 have impacted the way accounting - especially in terms of management - has been used by companies and accounting firms. In this context, the research aimed to identify how the crisis caused by COVID-19 has affected the management support offered by accountants. The study is characterized as a descriptive research, with a qualitative focus, whose operationalization was conducted by means of a previously defined script, with six accounting firms located in the states of Santa Catarina, Parana and Sao Paulo (Brazil). As for the data analysis, the content analysis technique was used. The results revealed that the COVID-19 crisis presented, in its first months, the potential to generate changes in the relationship between accounting firms and their clients, impacting the management support offered by accountants. Furthermore, it was observed that the consequences of the crisis led to a process of broadening the understanding of the role of accounting in the decision-making process. In this sense, the study contributes not only to the understanding of the ways in which the pandemic of COVID-19, in its initial stage, has influenced and continues to influence human relationships and, especially, professional relationships in the field of accounting, but also to show the opportunities arising from the moment experienced, so that accounting firms get closer to their clients.
\end{abstract}

Edited in Portuguese and English. Original version in Portuguese.

Received on 1/8/2021. Reviewed on 6/7/2021. Accepted on 6/24/2021 by Prof. Dr. Sergio Murilo Petri (Chief Editor) and Prof. Dr. Sandro Vieira Soares (Associate Editor). Published on 8/23/2021.

Copyright $\odot 2021$ RCCC. All rights reserved. Quoting parts of papers without prior authorization is allowed, provided the source is identified. 
Keywords: COVID-19. Accounting. Management support. Companies providing accounting services.

\section{INTRODUCTION}

The year 2020 featured the beginning of a pandemic arising from the new coronavirus, whose as yet uncertain origin is attributed to the Huanan Seafood Wholesale Market in Wuhan City, China, which presented the first cases of the disease as early as December 2019 (Crawford et al., 2020). As a response to the rapid transmission of the virus and the severity of those affected, the World Health Organization (WHO) declared, on March 11, 2020, when the cases of those infected reached more than 118,000 worldwide, that it was a pandemic (WHO, 2020).

Thus, since the first months of the year, as a way to reduce the effects of the disease, countries have announced the closure of establishments or changes in the operation of their activities, such as gyms, museums, movie theaters, and schools, among others (Sahu, 2020), generating direct impact on the lives of their citizens, on the economy of companies and on the country as a whole (Polizzi, Lynn, \& Perry, 2020; Sintema, 2020; Sahu, 2020). Despite this, there are today over 170.4 million people infected and over 3.5 million deaths worldwide from the effects of COVID-19 (WHO, 2021).

In Brazil, where the first case was recorded on March 4, 2020, according to data made available by the Ministry of Health (Brazil, 2020), little is known about the effects of the disease, whether in economic, political, or social terms. In this regard, it is known that one of the areas impacted by the effects of the pandemic is accountancy, whose dynamics and activities were affected, as well as the life and business of everyone around the world (Sintema, 2020). It is worth noting, however, that accounting can serve as a vector for facing and managing the economic crisis generated by COVID-19, resulting mainly from the closure of companies and the restriction of human mobility (Kraemer et al., 2020), which potentiated the global and Brazilian economic instability (Ferreira Junior \& Santa Rita, 2020).

Thus, accounting, especially in relation to the management aspect and support for decision-making, can help companies achieve their organizational objectives (Chenhall \& Langfield-Smith, 1998) which, at this point in time, can be translated into keeping companies active and overcoming the effects of the crisis caused by the pandemic. Despite this, there is an understanding that companies have not been able to absorb the usefulness of management accounting (Green \& Amenkhienan, 1992; Lukka \& Granlund, 2002; Abdel-Kader \& Luther, 2006), either due to a lack of knowledge and structure, or to the support offered by accountants, especially when they are served by accounting firms (Santos, Bennert, Figueiredo, \& Beuren, 2018).

In this context, it is understood that the pandemic of COVID-19 affected the lives and behavior of people around the world, generating feelings of uncertainty and anxiety about the future (Sahu, 2020; Sintema, 2020), both in personal and organizational aspects. Thus, it is suggested that these changes may also influence the way accounting, especially in the management aspect - which can be understood as the area whose focus is on partnering in decision-making related to management, with the aid in evaluating organizational performance, financial planning and control aspects (IMA, 2008) - has been used by companies and accounting firms, which can be seen, given the moment of insecurity, as a way out of the crisis, with accounting acting against suffering and inequality (Sargiacomo, Ianni \& Everett, 2014), in social and economic aspects. Therefore, this study seeks to answer the following research question: how has the crisis caused by COVID-19 affected the management support offered by accounting firms? To answer the proposed problem, the objective is to identify how the crisis has affected the management support offered by accountants.

Chahrour et al. (2020) show that COVID-19 has been the main focus of researchers around the world, with an amount of publications that exceeded 1,500 in March 2020. This 
movement has happened due to the unprecedented changes faced by all sectors of society from this pandemic (Polizzi et al., 2020; Massan, Shaikh, \& Dahri, 2020), as well as the search for a cure and reduction of the effects of the disease (Chahrour et al., 2020).

In this sense, studies have analyzed psychological (e. g., Wang et al., 2020), educational (e.g., Cao et al., 2020) and economic (e.g., Ferreira Junior \& Santa Rita, 2020) aspects at national and international levels. However, given the recent nature of the disease and its impacts, little is known yet about its effects worldwide and in Brazil. Thus, Massan et al. (2020) advocate the production of research related to the theme.

\section{MANAGEMENT SUPPORT OF ACCOUNTING FIRMS}

Management accounting can be seen as the area of accounting that has ane of its purposes the provision of financial controls and reports with a view to decision-making (IFAC, 1998; IMA, 2008). Such controls and reports can be provided from more sophisticated methods, tools or practices, such as the Balanced Scorecard, or, in a more simplified way, such as the use of traditional budgets and profit-based performance measures (Abdel-Kader \& Luther, 2006), representing a management support for decision-making at the organizational level.

In companies with restricted resources, as is the case of micro, small, and even mediumsized organizations, the adoption of such practices faces barriers related mainly to the lack of knowledge and structure (Ahmad \& Zabri, 2016). Thus, studies have been conducted in the search for understanding about how this area of knowledge has been used by less structured companies (e. g. Ahmad \& Zabri, 2016; Armitage, Webb \& Glynn, 2016; Prihastiwi \& Sholihin, 2018; Santos et al., 2018), which are the main ones impacted by the effects of a crisis.

Ahmad and Zabri (2016) conducted a study of 160 small and medium-sized enterprises in Malaysia, which aimed to identify the use of management tools. The results indicated a higher use of management accounting practices by medium-sized firms compared to small firms. Moreover, the most basic management techniques, such as budgeting, performance and costing were the most adopted among the analyzed companies. As a justification for this result, the authors suggest aspects such as the costs involved, practical aspects, and uncertainty related to the adoption of management tools.

The study by Armitage et al. (2016) aimed to identify the use of management accounting techniques by small and medium-sized companies in Australia and Canada. From 22 interviews (11 with companies from Canada and 11 with companies from Australia), the authors identified that industrial companies presented use of a greater amount of management tools and, in contrast, that smaller companies use such practices minimally, mentioning mainly cash flow control and management. In relation to the practices not used, the authors mention that the interviewees knew them, in most cases, but justified the non-use in function of the cost-benefit analysis, since resources are an element that is normally scarce among smaller organizations.

Prihastiwi and Sholihin (2018) conducted a study with small and medium-sized enterprises in Indonesia with the aim of identifying the level of adoption of management tools. From the 124 responses obtained, they identified that the main practices used by companies were those considered traditional, to the detriment of newer ones. Regarding the factors that justify this application, the authors identified that the qualification of the accounting team, the size and the participation of the owner or manager had influence in the adoption of management practices. Therefore, in addition to other factors, the relationship between the accountant and the company regarding management support appears here.

Santos et al. (2018) sought to verify the role of accounting firms in the use of management practices by small and medium-sized Brazilian companies. From the response of 39 companies, the authors identified that most managers are unaware of or do not use management tools. In relation to those that do use some tool for business management, these are not provided 
by the accounting firm, which may indicate communication noises between clients and their accounting service providers.

Thus, it can be seen that accountants and accounting firms are also part of the context of low use of management tools by corporations, because part of these professionals or firms do not seem to provide support for these companies to professionalize their management. In times of crisis, this fact becomes more crucial, given the need for a faster decision-making process to face the effects of COVID-19 and since, as Ahmad (2012) argues, companies - especially small and medium-sized ones - must use accounting information to deal with future challenges. In this sense, it is understood that, although the studies show low use of management tools by small companies and the low supply of this service by accounting firms, a crisis, such as the one generated by the new coronavirus, can change this situation.

\section{METHODOLOGICAL PROCEDURES}

With regard to the methodological framework, the study used the categorization proposed by Sampieri, Collado and Lucio (2013). Thus, it is characterized as a non-experimental, crosssectional, descriptive survey with a qualitative focus.

In operational terms, it was decided to use interviews. The interview technique "provides the basic data for the development and understanding of the relationships between social agents and their situation" (Gaskell, 2015, p. 65), aiming at a detailed understanding about the behaviors of individuals in specific social circumstances. Such technique was semi-structured and in-depth (Martins \& Theophilo, 2016), since it was conducted by a script, but with freedom to add new questions in the course of the process.

The semi-structured script used was prepared by the authors and contains questions derived from the researchers' concerns about the new moment that the world is experiencing, due to the COVID-19 pandemic (Sahu, 2020), which affects companies, accountants and the provision of accounting services.

It should be noted that before the interviews were conducted, two specialists in the accounting area who have also conducted research on the theme of the new coronavirus validated the semi-structured script. After the validation, not only were adjustments made to some questions, but also others were added to the interview script. Additionally, its separation by blocks was also a result of the specialists' notes. Thus, the final interview script used in the research is composed of 14 questions, divided into three blocks: Management Support; Interviewee Profile; and Company Profile. Table 1 presents the details of the final script, with the questions in each block.

\section{Table 1}

\section{Final Survey Script}

Management Support
1. What do you understand by management support? What kind of management support should an accountant
offer to his or her clients today?
2. In your perception, are accountants seen by companies as management support when faced with such a
pandemic?
3. Do you believe that your clients see your firm as a key element in maintaining the health of their company? Do
you think the crisis generated by COVID-19 can change this view?
4. What management support services do you used to offer your clients?
5. Did these services change with the arrival of the COVID-19 Pandemic? If yes, what were the changes? What
encouraged these changes within the accounting firm?
6. How might the crisis generated by COVID-19 change the relationship between client and accountant in the
short and long term?
7. In your perception, has the vision of the management support that accountants can offer to companies changed
as a result of COVID-19? Do these modifications tend to accompany the services provided in the long term?
8. Did you notice an increase in demand for accountants during the pandemic of COVID-19? If yes, why do you


think this happened? What political, economic and social scenario contributed to such behavior of people? Some provocations: provisional measures related to employment, the possibility of suspending tax payments, and the possibility of financing.

\begin{tabular}{|c|}
\hline Interviewee Profile \\
\hline 1. How many years has your accounting firm been in business? \\
\hline 2. What is your major education? Some provocations: specialization, master's and doctorate. \\
\hline Company Profile \\
\hline $\begin{array}{l}\text { 1. In which city is your accounting firm located? In case there is more than one unit, consider the head office or } \\
\text { main office. }\end{array}$ \\
\hline 2. How many employees/collaborators does the firm have? \\
\hline 3. Approximately how many clients does your firm have? \\
\hline $\begin{array}{l}\text { 4. In your view, what is the profile of your clients? Some provocations: micro and small companies, medium } \\
\text { size, large size, and family structure. }\end{array}$ \\
\hline
\end{tabular}

It is noteworthy that we chose not to direct the respondents with questions that included the attributes of management support, since the focus is on understanding their perceptions, in greater depth, from the study participants. Therefore, the understanding about the management support and how it was offered before and after the pandemic was obtained from the vision of the interviewees. Additionally, it should be mentioned that, in terms of the size of the clients of the offices participating in the research, their subjective classification was chosen, yet based on the perception of the interviewees.

The target population of the research consisted of accounting firms, and the selection of participants was based on convenience and accessibility - partners-owners of accounting firms in Parana, Santa Catarina and Sao Paulo who agreed to participate in the research. The selected firms had different structures and sizes, in order to identify, in the different cases, how the COVID-19 pandemic influenced the supply of management support. Initially, a first contact was made with the potential participants (accounting firm owners), in which the objective of the study was explained. After they agreed to participate in the research, a date and time were scheduled for the interviews. At no time were the participants coerced into participating in the study, and no material or immaterial reward was offered to the research group of interest. Before the interview began, a further explanation was made about the purpose of the study, as well as a brief presentation of the script and of the researchers. At this moment, the participants' authorization to record the interview was also requested.

The interviews were conducted online, justified by the geographical location of the participants (Parana, Santa Catarina and Sao Paulo) and by the pandemic itself. Although the online interview has some limitations, among them "the nonverbal or paralinguistic parts of the communication [which] are difficult to transport and integrate" (Flick, 2009, p. 243), it is a way to replace an in-person interview, and has the advantage of integrating to the investigation participants who are not accessible, such as those who live far away. Thus, given the choice for online operationalization, the interviews were conducted through Skype and Zoom apps.

The meetings took place between May 13 and 29, 2020, approximately two months after the pandemic arrived in Brazil, with an average duration of 33 minutes, as shown in Table 2.

Table 2

\section{Interview Data}

\begin{tabular}{l|c|c|c}
\hline \multicolumn{1}{c|}{ Participant } & Date & Duration & Tool \\
\hline Interviewee 1 & $05 / 13 / 2020$ & $00: 46: 28$ & Zoom \\
\hline Interviewee 2 & $05 / 14 / 2020$ & $00: 24: 55$ & Skype \\
\hline Interviewee 3 & $05 / 20 / 2020$ & $00: 18: 50$ & Skype \\
\hline Interviewee 4 & $05 / 05 / 2020$ & $01: 01: 10$ & Skype \\
\hline Interviewee 5 & $05 / 28 / 2020$ & $00: 23: 33$ & Skype \\
\hline Interviewee 6 & $05 / 29 / 2020$ & $00: 25: 41$ & Skype \\
\hline
\end{tabular}

Source: Research data (2020). 
As for the saturation of data collection, we sought, in the research process, to flesh out the object of study, not worrying about the quantity of interviews, but with the quality of information. Minayo (2017) points out that researchers have spoken out regarding the questions about the moment of saturation in qualitative research, but there is no definitive consensus on the issue. Thus, it is highlighted that, during the period of the interviews, the researchers evaluated the saturation of the responses obtained and identified that such a fact happened at the time of obtaining 6 participants, when, despite the differences in terms of structure, there was a repetition in the answers given. Therefore, as Miyano (2017) refers, saturation occurred by the researchers' vision when they realized they had found the internal logic of the study object, even verifying the characteristic of direct and simple verbal expressions in the interviewees' speeches.

After the interviews were finished, they were transcribed for analysis purposes. Once the transcription was done, it was possible to create analysis categories. Categorization "[...] is a structuralist type process and it involves two steps: the inventory (isolation of the units of analysis: words, themes, phrases etc.) and the classification of common units, revealing the categories (placement in drawers) [...]" (Martins \& Theóphilo, 2016, p. 99).

Once these procedures were done, the data collected from the interviews were treated with the content analysis technique. Content analysis is a technique to produce inferences in an objective way (Bauer, 2015). According to Bardin (2009), content analysis is "a set of communication analysis techniques aiming to obtain, through systematic and objective procedures of the description of the content of messages, indicators (whether quantitative or not) that allow the inference of knowledge related to the conditions of production/reception [...] of these messages" (p. 44). In the analysis of the interviews, the participants were coded so that they would not be identified.

\section{PRESENTATION AND DISCUSSION OF RESULTS}

In terms of the characterization of the interviewees and their firms, there is a variety both in relation to the time of activity and the size, whether in terms of the number of clients or the number of employees. The data referring to this characterization are presented in Table 3.

Table 3

Characterization of the participants and their accounting firms

\begin{tabular}{|c|c|c|c|c|c|}
\hline Respondent & Educational Background & $\begin{array}{c}\text { Firm } \\
\text { operation }\end{array}$ & $\begin{array}{c}\text { No. of } \\
\text { employees }\end{array}$ & $\begin{array}{l}\text { No. of } \\
\text { client } \\
\text { S }\end{array}$ & $\begin{array}{l}\text { Size of } \\
\text { clients }\end{array}$ \\
\hline Interviewee 1 (E1) & $\begin{array}{c}\text { Technician in Accounting, } \\
\text { undergraduate in Business } \\
\text { Administration and graduate } \\
\text { in Pedagogy }\end{array}$ & 30 years & 15 & 70 & $\begin{array}{l}\text { Small to } \\
\text { medium } \\
\text { size }\end{array}$ \\
\hline Interviewee 2 (E2) & $\begin{array}{c}\text { Post-graduation in } \\
\text { Accounting, Labor and Tax } \\
\text { Expertise }\end{array}$ & 1 year & 0 (2 members) & 12 & $\begin{array}{l}\text { Micro and } \\
\text { small }\end{array}$ \\
\hline Interviewee 3 (E3) & $\begin{array}{l}\text { Post-graduation in tax area in } \\
\text { progress }\end{array}$ & 10 years & 2 & 50 & $\begin{array}{l}\text { Micro and } \\
\text { small }\end{array}$ \\
\hline Interviewee 4 (E4) & Master in Accounting & 6 years & 40 & 250 & $\begin{array}{l}\text { Small to } \\
\text { medium } \\
\text { size }\end{array}$ \\
\hline Interviewee 5 (E5) & Bachelor in Accounting & 60 years & 10 & 250 & $\begin{array}{l}\text { Small to } \\
\text { medium } \\
\text { size }\end{array}$ \\
\hline Interviewee 6 (E6) & $\begin{array}{l}\text { Master's in accounting in } \\
\text { progress }\end{array}$ & 5 years & 2 & 40 & $\begin{array}{l}\text { Micro and } \\
\text { small }\end{array}$ \\
\hline
\end{tabular}

Source: Research data (2020). 
It can be seen, therefore, that the interviewees have firms that serve companies of different sizes and that are also at different stages, in terms of their constitution as a company and in relation to their structure.

This heterogeneity among the interviewees is reflected in the way they understand management support and the possibilities for their accounting firms to offer such support. In terms of understanding about management support, it is possible to perceive a general understanding related to aiding in decision-making, in line with what the IMA (2008) recommends about the role of management accounting and accountants. Nevertheless, it is possible to observe, as to the depth of the term, a distance in the answers. These distances can be seen in the statements of interviewees E3 and E4, who assert that "The management that I understand would be this, this accounting up to date, so that, with the calculated result, we can be able to pass information to the client.. [...]" (E3) and "[...] the accountant has a key role in this, either by offering financial services, helping in business management, [...] aiding in the organization and determination of internal processes, internal control processes, generation of information in real time" (E4).

Regarding what should be offered to clients, we noticed a distinction in relation to the direction that respondents indicate as the focus of management support. On one hand, there is a vision that is more related and limited to decision-making in the financial and tax scope; on the other hand, there is a vision of a support that seems to be more related to the aspects of the achievement of organizational objectives, as can be identified from the statements of interviewees E5, E2 and E4. Interviewee 5 stated that "[...] mainly support in the financial area, such as how to control their finances, how to use tools and methods to determine results, how to internally apply management systems and tools that really generate information in real time [...]". In addition, Interviewee 2 pondered that "[...] and then I believe that the management part goes deeper, in terms of its own indexes; finally, management instruments that can really help and bring an effect to the company, a greater result for the company". Finally, in addition, Interviewee 4 defended that

[...] to precisely provide this required management support, whether at the cash flow level, whether at the level of indicators, whether at the level of projection of results, tax planning, and so on, I think there is a lot of information that the accountant can help provide and often also help to understand the results (E4).

Therefore, it is noted that the vision of the interviewees about what the management aspect consists of and the possibilities of offering related tools is more focused on the initial stages of management accounting, as defined by IFAC (1998), where the focus is centered on determining costs and financial control. In this sense, considering that most of the clients of the analyzed firms are small and medium-sized companies, and that the interviewees understand management support as an aspect focused on financial control, these findings seem to align with those of Armitage et al. (2016), who identified that smaller companies have their management support focused on financial information.

However, it can be seen that accounting firms do not seem to be offering management support at this level, and that this fact may be related to barriers that are imposed by the clients themselves, as highlighted by interviewees E1 and E2. Interviewee 1 stated that "[...] we are not yet at this level of management support; I believe that we are at an operational support level. At least the vast majority, in terms of accounting office" (E1). Moreover, E2 observed that

What I see as a difficulty in providing management information, is that many times, it is not interesting for the entrepreneur himself, he does not see the accountant as a person 
who can help in this sense [...] very few entrepreneurs have this feeling of wanting the accountant to get involved (E2).

Similarly, Ahmad and Zabri (2016) identified that some barriers influence not only the provision of management support, but also the adoption of their tools by companies, and are related to the lack of knowledge and structure, especially on the part of small companies, which also seem to be the barriers faced by the interviewed accounting firms and their clients.

In relation to the initial impacts of the COVID-19 pandemic on the demand for accounting firms, there was a considerable increase in work, especially in the first weeks after the pandemic arrived in the country, related mainly to labor and tax aspects. About this question, the respondents use terms such as "working more than 24 hours a day" (E1), "those were very busy weeks" (E2), "it was pretty crazy" (E2), "it was really crazy" (E3), "we must have received more than a thousand WhatsApp messages a week" (E4). The interviewees also report that the accountant was seen as a support for the understanding of the options arising from the publications of provisional measures (suspension and reduction of working hours, for example), extensions of tax and labor deadlines and possible labor agreements linked to the critical moment of the pandemic. These perceptions can be perceived by the statements of interviewees E2, E3, E5 and E6, as summarized in Table 4.

Table 4

\section{Perception of support from accounting firms to companies}

\begin{tabular}{c|l}
\hline Interviewee 2 & $\begin{array}{l}{[\ldots] \text { because I felt like a doctor, like when I am dying I will look for the accountant [...] then }} \\
\text { there is a need for the entrepreneur to have the accountant by his side, I think it was very } \\
\text { evident this increase in demand, this search for problem resolutions. [...] but it was in the sense } \\
\text { of asking for help, for guidance, so I felt this quite clearly. }\end{array}$ \\
\hline Interviewee 3 & $\begin{array}{l}{[\ldots] \text { he doesn't have what to do with his employee, so he calls us: 'What should I do? Has the }} \\
\text { government issued a law? Any provisional measure?' }\end{array}$ \\
\hline Interviewee 5 & $\begin{array}{l}{[\ldots] \text { however many businessmen say that the accountant is a necessary evil, it is at this point }} \\
\text { that the accountant comes to solve the problem. [...] our employees have spent a lot of time in } \\
\text { these last two months more understanding what has to be done than actually doing it, because } \\
\text { this part has been really hit. }\end{array}$ \\
\hline Interviewee 6 & $\begin{array}{l}\text { So our demand has increased a lot in this, as I told you, practically in these two months we have } \\
\text { become a personnel department consultant, a few demands that have increased in the tax area } \\
{[\ldots] .}\end{array}$ \\
\hline
\end{tabular}

Source: Survey data (2020).

In line with what has already been reported, the interviewees indicated there is the perception that the accountant is seen by companies as management support in the face of a pandemic such as COVID-19, mentioning that business owners perceived a greater dependence on the accountant, accepting more suggestions, and showing more respect for the work performed by this professional, as presented by the interviewees. Interviewee 1 mentions that "[...] I did feel that they perceived the great dependence on the accountant, quite a lot, they surely realize this $[\ldots](\mathrm{E} 1)$. Additionally, interviewees E2, E4 and E5 present similar perceptions, as presented in Table 5. 
Table 5

\section{Perception of management support by the offices for the companies}

\begin{tabular}{c|l}
\hline Interviewee 2 & $\begin{array}{l}\text { I think that in the moment of desperation, the entrepreneur ends up accepting that the } \\
\text { accountant enters as a support, in fact, and not only as the closing or maintenance of the } \\
\text { accounting routine [...]. But I did feel a difference in the search and acceptance of this } \\
\text { participation of the accountant in the midst of the pandemic. }\end{array}$ \\
\hline Interviewee 4 & $\begin{array}{l}\text { [...] we noticed, mainly me, a much greater approach of the accountant to the businessmen in } \\
\text { the sense of decision-making, for example, whether in a reduction analysis, suspension of the } \\
\text { employment contract, projection, or helping many entrepreneurs to reevaluate new businesses } \\
\text { or new business possibilities, to redesign their own business and to understand how this can } \\
\text { affect them financially, or even help in the decision process of obtaining financing [...]. }\end{array}$ \\
\hline Interviewee 5 & $\begin{array}{l}{[\ldots] \text { but at this time of crisis, many entrepreneurs started to value and respect the accountant's }} \\
\text { work, because they see how the accountant can lend a hand, how they can help at this time. }\end{array}$ \\
\hline
\end{tabular}
Source: Survey data (2020).

There seems to be, therefore, a direction towards the use of accounting information for the management challenges of companies that are assisted by accounting firms, whose owners were interviewed in the face of the new coronavirus crisis, which is in line with what Ahmad (2012) advocates in terms of the use of such information, especially by smaller companies: it should be used to face possible challenges during their existence. It is worth noting that, in the midst of a pandemic such as the one currently experienced, the accountant's partnership in decisions related to personnel management, such as reduction of workload, layoffs, vacations, among others, may be essential to ensure the maintenance of the organization.

About the vision of how the firm works as an element for maintaining the health of companies and how the new coronavirus crisis, even in its early stages, has changed such vision, it was found that the participants see two distinct client profiles. On the one hand, those who, in general, are larger and see accounting as a source of information; on the other, the businessmen who see the accountant only as a cost for their business. In this respect, terms such as "I believe we have both profiles" (E5), "clients of various models" (E4) and "it depends a lot on the size of the company" (E6) were used. Thus, such findings seem to be related to those of Prihastiwi and Sholihin (2018) regarding mainly the size and characteristics of the managers, who are able to influence the perception about the ability of the accounting firm or the accountant as sources of information for maintaining the health of their companies. Regarding the changes caused by the pandemic, the reports do not show unanimity, but mostly present positive views, as can be seen in the statements of interviewees E1, E4, E5, and E6, presented in Table 6.

\section{Table 6}

\section{Changes caused by the pandemic}

\begin{tabular}{c|l}
\hline $\begin{array}{c}\text { Interviewee } \\
1\end{array}$ & $\begin{array}{l}\text { For sure the crisis generated by COVID can change this view, I see that from then on they will } \\
\text { have a different view [...]. Necessity will make companies look much more for accounting today } \\
\text { than before the pandemic, that's very likely, I cannot say this for sure, but I believe that there will } \\
\text { be a very significant change at this point. }\end{array}$ \\
\hline $\begin{array}{c}\text { Interviewee } \\
4\end{array}$ & $\begin{array}{l}\text { It will surely change, actually it is already changing [...] so I believe that this whole crisis will } \\
\text { bring this very digital change in the accounting vision, in the need for information [...]. }\end{array}$ \\
\hline $\begin{array}{c}\text { Interviewee } \\
5\end{array}$ & $\begin{array}{l}{[\ldots] \text { if the pandemic can affect? Sure, it can. As I said, we have customers who did not see the }} \\
\text { value and will start seeing it from this moment on, so I believe it can. }\end{array}$ \\
\hline $\begin{array}{c}\text { Interviewee } \\
6\end{array}$ & $\begin{array}{l}\text { About COVID-19, yes, the perception of some companies ends up changing, so they can see } \\
\text { accounting in a little different way [...]. }\end{array}$ \\
\hline
\end{tabular}

Source: Survey data (2020).

In relation to the management support services offered to clients and the changes brought about by the pandemic of COVID-19, it was noted that there is a categorization of responses, which are divided between accounting firms that did not offer the service, others that offered it as an additional service, and those that offered it along with the other services provided. The 
firms that did not offer the service continued not to offer management support to their clients. Among those that offered it as an additional service, it was observed that in one case there were no changes, while in the other there was a change in the supply of the service due to a greater demand from clients, mainly related to the financial aspect and the personnel department, as evidenced in the speech of interviewee E1.

My firm is a bit differentiated, it remains not only in the operation, it is also very focused in the management, but this is a particularity of mine because I add to it a more technical management consulting issue [...]. What happened after the pandemic, [...] was that we had a bit of participation in the decisions [...] [...] yet regarding the more financial issue [...], we participated more in this, like, suspension of labor contracts, how this will impact the cost, the suspension of taxes, for example, there were changes in these areas (E1).

As for the accounting firms that offered management support along with the other services, we noticed changes mainly related to client demands, but not necessarily to the inclusion of new management tools or techniques, as can be identified from the statements of interviewees E4, E5 and E6. E4 pondered that "they have changed a little, I think they have increased, they have been increasing, there were clients asking for help [...] so there has been a lot of work in this aspect too, which perhaps would not have occurred if there was no COVID19 " and "unbelievably, there are some companies that have called me up, I am doing consulting for companies that are not actually my accounting clients [...]" (E4). Moreover, E5 mentioned that "[...] they have changed, in the sense of increasing, in the sense that new doubts arise every moment, you have to give this support, in this sense, yes [...]" (E5). Finally E6 affirmed that

$[\ldots]$ what has changed now [...], is that when many decrees started coming in and when companies started closing down, the focus of our clients here at the firm changed a lot, our clients turned to the personnel department [...] (E6)

It should be noted that management support, when offered by accounting firms, consists of tools related mainly to the first stage of management accounting presented by IFAC (1998), with decisions focused mainly on financial aspects. However, for this scenario to change, it is necessary to involve both parties (accountants and entrepreneurs), with a joint search that leads to the use of information and management tools of more advanced stages. On this point, the COVID-19 pandemic seems to have been, albeit slowly and gradually, an impulse for this situation to change.

In terms of changing the vision about the possibilities of management support offered by accounting firms to companies as a result of COVID-19, the interviewees' statements indicate that the change was already happening from the accountant's perspective, but with restrictions from their clients, as evidenced earlier. In this sense, it seems that the crisis generated by COVID-19, still in its initial phase, accelerated the process of convergence about the vision of the usefulness of management support between the accountant and the client, generating a trend toward the understanding that accounting, through this tool, can be present as a generator of information in the decision-making process, helping the entrepreneur. This understanding can be observed in the statements of interviewees E1, E2, E3, and E4. E1 defended that "the crisis will bring a more knowledgeable, more technical professional to help support, and will push away the mechanical support, the operational support a little more" (E1). Moreover, E2, E3 and E4 have the same vision, as summarized in Table 7. 
Table 7

\section{Perception of the usefulness of management support}

\begin{tabular}{c|l}
\hline Interviewee 2 & $\begin{array}{l}\text { I think that even as far as accountants are concerned, maybe they have brought a little more } \\
\text { feeling, but I think that they have been bringing it for a long time [...], but now maybe they have } \\
\text { got more possibility and more openness to become concrete, let's put it this way. }\end{array}$ \\
\hline Interviewee 3 & {$[\ldots]$ so I think that COVID-19 only accelerated a process that was already being developed [...]. } \\
\hline Interviewee 4 & $\begin{array}{l}\text { No, I do not think that COVID-19 changed it, I think that it rather intensified it. As I said, this } \\
\text { had already been happening in our area [...] it was not COVID-19 that changed the need to } \\
\text { generate management information for customers, I think that this had already been happening, it } \\
\text { had already been in a scenario, so much so that people say that accounting as we know it, two or } \\
\text { three years ago people said that it would end, and it is a reality [...]. }\end{array}$ \\
\hline
\end{tabular}

Source: Survey data (2020).

With regard to the relationship between client and accounting firm, there seems to be a notion of a closer relationship, either generated directly by COVID-19 or accelerated by it. In addition, a perception of distancing from the operational characteristic of accounting, normally offered by accounting firms, was identified, as well as the direction of offering accounting with more management characteristics, both in the short and long term. These findings can be confirmed by the statements of interviewees E1, E2, E3, E4, and E6, as shown in Table 8.

Table 8

\section{Perception of a closer relationship between clients and accountants}

\begin{tabular}{|c|c|}
\hline Interviewee 1 & $\begin{array}{l}\text { So, maybe this crisis will bring the companies a little closer to the accountants who follow this } \\
\text { management line, that's an assumption, and will distance them a little more from those who do } \\
\text { not operate along this line, who only make a mechanical reproduction of data. I think that the } \\
\text { crisis will select this a little, this relationship will become closer, from the point of view of } \\
\text { partnership, trust, and knowledge, and less from the operational part, in my opinion. }\end{array}$ \\
\hline Interviewee 2 & $\begin{array}{l}{[\ldots] \text { I think that the client will understand more what the accounting universe can bring to him, }} \\
\text { not only in terms of legal and accounting security, and so on, but also in terms of financial } \\
\text { planning and other tools that we end up not getting into so deeply because of this blockage } \\
\text { between parties. [...] I think it can have a different mentality, I think it will not be too radical, I } \\
\text { see that there is still a lot of blocking, this closed mentality, but I think it can bring changes. }\end{array}$ \\
\hline Interviewee 3 & I think that it will change a lot in the short term. \\
\hline Interviewee 4 & $\begin{array}{l}\text { I think that this change is already happening, it is not COVID-19 that will make this change } \\
\text { happen [...] So, maybe COVID-19 will accelerate this process a little bit [...] so this was already } \\
\text { happening, with COVID-19 I think this will intensify because now he needs to make quick } \\
\text { decisions [...]. }\end{array}$ \\
\hline Interviewee 6 & $\begin{array}{l}{[\ldots] \text { now, the company that saw this as an opportunity, or perceived the moment to change the }} \\
\text { way it operates, it will tighten its bonds even more, because as you are maybe changing your } \\
\text { line of business, or the way you operate, or you saw the real use of accounting or the } \\
\text { information that we generate, this guy will tighten his bonds a lot, in the sense of increasing a } \\
\text { demand more focused on consulting, for the management of companies [...]. }\end{array}$ \\
\hline
\end{tabular}

Source: Survey data (2020).

The understanding about the closer relationship between accountants - or accounting firms - and their clients seemed to ease one of the problems evidenced from the findings of Santos et al. (2018) in terms of the noises apparently existing in the communication between them, generating an environment of greater integration where the supply of management support can be expanded, allowing the supply of tools that assist companies in business management.

Therefore, it can be noticed that the initial impacts generated by COVID-19 in the provision of management support by accounting firms have occurred, mainly, as a consequence of the increase in client demands that required quick decisions, as well as the understanding of the financial and operational possibilities and consequences of decision-making. It is also worth mentioning that this demand occurred mainly due to the provisional measures and changes in legislation adopted upon the arrival of the virus in Brazil. Besides, an opportunity has been seen, 
in the crisis, to bring clients and accounting offices closer together, contributing to or accelerating the movement of valuing accountants and the service provided by accounting offices regarding the management aspect. These views seem to be more present among larger companies served by accounting firms, while micro and small companies seem to be, still, at an early stage regarding such approximation.

\section{FINAL CONSIDERATIONS}

This study aimed to identify how the crisis caused by COVID-19 affected the management support offered by accountants based on the analysis of interviews with 6 accounting firms located in the states of Sao Paulo, Parana and Santa Catarina. Based on the data, it was identified that the COVID-19 crisis, still in its early stages in Brazil, presented potential for changes in the relationship between accounting firms and their clients, impacting the support offered by accountants.

Thus, we can notice that the consequences of the crisis caused by COVID-19, as experienced by companies, have led to a process of broadening the understanding of the role of accounting, by means of accounting firms and their accountants, with regard to the decisionmaking process, which has influenced an increase in the management support offered by accounting service firms. In this aspect, it also seems that the size and structure of both the accounting firms and the companies that use their services impact the supply and adoption of notions and tools related to management support.

Thus, we sought to contribute to the understanding of the ways in which COVID-19, albeit in its early stages, has influenced human relationships and, especially, professional relationships in the accounting field. In this sense, the knowledge generated from the results of this study can contribute to the confrontation and understanding of other crises/contingencies that might occur, such as environmental disasters, strikes, and essential public services downtime, among others. Moreover, it also contributes by showing the opportunities arising from the moment in which they are living, so that accounting firms can get closer to their clients, enabling their insertion in the decision-making process of companies, helping to overcome the current crisis and generating more value from the services they offer.

As an implication, there is, therefore, a moment for accounting firms - in possession of their ability to assist companies in overcoming the crisis - to take upon themselves an opportunity to ease the suffering of entrepreneurs, helping them in decision-making that allows their businesses to survive during the contingencies faced in the period and, at the same time, to present themselves as a source of information and support, especially management, which can generate value for companies even in times that are not as delicate as the current one. In this sense, an opportunity arises for accountants to increase the entrepreneurs' understanding that accounting can go beyond the operational aspect, with the supply of management tools or techniques, either simple or complex, that can help the companies' management.

The results should be interpreted considering some limitations, such as the use of interviews and the time when the study was conducted - when the effects of COVID-19 may not have been fully felt, since the interviews were conducted in the early stages of the pandemic. In addition, it should be considered that the size of the clients to whom the survey participants serve was obtained from the perception of the interviewees, taking into account mainly tax aspects. Other limitations relate to the profile of the interviewees, who used direct and simple verbal expressions during their speeches, and the reality of the type of company used in the research (accounting firms). Furthermore, we suggest that surveys that seek to expand the scope of participants in quantitative or qualitative terms are carried out, analyzing the relationships investigated in this study with an extension of the period in relation to the emergence of the COVID-19 pandemic, seeking to identify the effects generated in the long term, as well as surveys that extend the findings of this study by analyzing, for example, the divergence between 
theory and practice regarding aspects related to management support, and how the pandemic has changed (or not) these differences.

\section{REFERENCES}

Abdel-Kader, M. G., \& Luther, R. G. (2006). IFAC's conception of the evolution of management accounting. Advances in Management Accounting, 15, 229-247.

Ahmad, K. (2012). The use of management accounting practices in Malaysian SMEs. Dissertation $(\mathrm{PhD})$, University of Exeter, United Kingdom.

Ahmad, K., \& Zabri, S. M. (2016). Management accounting practices among small and medium enterprises. Proceedings of the $28^{\text {th }}$ International Business Information Management Association Conference, 9, 10.

Armitage, H. M., Webb, A., \& Glynn, J. (2016). The use of management accounting techniques by small and medium-sized enterprises: a field study of Canadian and Australian practice. Accounting Perspectives, 15(1), 31-69.

Bardin, L. (2009). Análise de conteúdo. Lisbon: Edições 70.

Bauer, M. W. (2015). Análise de conteúdo clássica: uma revisão. In M. R. Bauer, \& Gaskell, G. (Orgs). Pesquisa qualitativa com texto, imagem e som: um manual prático. Petropolis, RJ: Vozes.

Brazil. (2020) Painel de casos de doença pelo coronavírus 2019 (COVID-19) no Brasil pelo Ministério da Saúde. Retrieved from https://covid.saude.gov.br

Cao, W., Fang, Z., Hou, G., Han, M., Xu, X., Dong, J., \& Zheng, J. (2020). The psychological impact of the COVID-19 epidemic on college students in China. Psychiatry research, 112934.

Chahrour, M., Assi, S., Bejjani, M., Nasrallah, A. A., Salhab, H., Fares, M., \& Khachfe, H. H. (2020). A bibliometric analysis of Covid-19 research activity: A call for increased output. Cureus, 12(3).

Chenhall, R. H., \& Langfield-Smith, K. (1998). Adoption and benefits of management accounting practices: an Australian study. Management accounting research, 9(1), 1-19.

Crawford, J., Butler-Henderson, K., Rudolph, J., Malkawi, B., Glowatz, M., Burton, R., Magni, P., \& Lam, S. (2020). COVID-19: 20 countries' higher education intra-period digital pedagogy responses. Journal of Applied Learning \& Teaching, 3(1), 1-20.

Ferreira Junior, R. R. F., \& Santa Rita, L. P. (2020). Impactos da Covid-19 na Economia: limites, desafios e políticas. Cadernos de Prospecção, 13(2), 459-476.

Flick, U. (2008). Introdução à pesquisa qualitativa. Porto Alegre: Artmed.

Gaskell, G. (2015). Entrevistas individuais e grupais. In M. R. Bauer; G. Gaskell (Orgs). Pesquisa qualitativa com texto, imagem e som: um manual prático. Petropolis, RJ: Vozes. 
Green, F. B., \& Amenkhienan, F. E. (1992). Accounting innovations: a cross sectional survey of manufacturing firms. Journal of Cost Management for the Manufacturing Industry, 6(1), 5864.

International Federation of Accountants (IFAC) (1998). International Management Accounting

Practice

Statement:

Management

Institute of Management Accountants (IMA). (2008). Definition of Management Accounting. Statements on Management Accounting.

Kraemer, M. U., Yang, C. H., Gutierrez, B., Wu, C. H., Klein, B., Pigott, D. M., ..., \& Brownstein, J. S. (2020). The effect of human mobility and control measures on the COVID19 epidemic in China. Science, 368(6490), 493-497.

Lukka, K., \& Granlund, M. (2002). The fragmented communication structure within accounting academia: the case of activity-based costing research genres. Accounting, Organizations and Society, 27(1), 165-190.

Martins, G. A., \& Theóphilo, C. R. (2016). Metodologia da investigação científica para ciências sociais aplicadas. Sao Paulo: Atlas.

Massan, S., Shaikh, M. M., \& Dahri, A. S. (2020). Effect of COVID-19 epidemic on research activity of researcher in Pakistan Engineering University and its solution via technology. 3C Tecnología. Glosas de innovación aplicadas a la pyme, (Edición Especial), 249-263.

Minayo, M. C. S. (2017). Amostragem e saturação em pesquisa qualitativa: consensos e controvérsias. Revista pesquisa qualitativa, 5(7), 1-12.

Polizzi, C., Lynn, S. J., \& Perry, A. (2020). Stress and Coping in the Time of Covid-19: Pathways to Resilience and Recovery. Clinical Neuropsychiatry, 17(2).

Prihastiwi, D. A., \& Sholihin, M. (2018). Factors Affecting the Use of Management Accounting Practices in Small and Medium Enterprises: Evidence from Indonesia. Journal Dinamika Akuntansi, 10(2), 158-176.

Sahu, P. (2020). Closure of universities due to Coronavirus Disease 2019 (COVID-19): impact on education and mental health of students and academic staff. Cureus, 12(4).

Sampieri, R. H., Collado, C. F., \& Lucio, P. B. (2013). Metodologia da Pesquisa. Sao Paulo: McGrauw-Hill, 2013.

Santos, V. D., Bennert, P., Figueiredo, G. H., \& Beuren, I. M. (2018). Uso dos instrumentos de Contabilidade Gerencial em pequenas e médias empresas e seu fornecimento pelo escritório de Contabilidade. Pensar Contábil, 20(71).

Sargiacomo, M., Ianni, L., \& Everett, J. (2014). Accounting for suffering: Calculative practices in the field of disaster relief. Critical Perspectives on Accounting, 25(7), 652-669. 
Sintema, E. J. (2020). Effect of COVID-19 on the performance of grade 12 students: Implications for STEM education. Eurasia Journal of Mathematics, Science and Technology Education, 16(7), 1851.

Wang, C., Pan, R., Wan, X., Tan, Y., Xu, L., Ho, C. S., \& Ho, R. C. (2020). Immediate psychological responses and associated factors during the initial stage of the 2019 coronavirus disease (COVID-19) epidemic among the general population in China. International journal of environmental research and public health, 17(5), 1729.

World Health Organization (WHO). (2020). Coronavirus disease 2019 (COVID-19) - Situation Report - 51. Retrieved from https://www.who.int/docs/default-source/coronaviruse/situationreports/20200311-sitrep-51-covid-19.pdf?sfvrsn=1ba62e57_10

World Health Organization (WHO). (2021). WHO Coronavirus (COVID-19) Dashboard - 01 June 2021. Retrieved from https://covid19.who.int/ 